\title{
Children's Rights in The Perspective of Primary School Teachers in The Period COVID-19 Epidemic
}

\author{
Behiye DAĞDEVIREN ERTAŞ * \\ Department of Educational Sciences, Education Faculty, Yozgat Bozok University, Yozgat, \\ Turkey ORCID: 0000-0003-2431-1914
}

Onur BATMAZ

Health Services Vocational School, Yozgat Bozok University, Yozgat, Turkey ORCID: 0000-0001-9208-2645

\begin{abstract}
Ahmet KILIÇ
Health Services Vocational School, Yozgat Bozok University, Yozgat, Turkey
\end{abstract} ORCID: 0000-0001-7147-8552

Article history

\section{Received:}

09.05.2021

Received in revised form: 06.12.2021

Accepted:

19.12.2021

Key words:

Children's Rights,

COVID-19,

Primary School Teachers.
With the announcement of an epidemic by the World Health Organization in 2020, countries have been restricted in many areas such as economy, health, education, and social life. With this restriction process, it is possible to say that children experience difficulties accessing many salient services, especially education, health, and care services. Therefore, during the COVID-19 epidemic, children can be told that they are deprived of rights based on their protection and development. In this process, the research aims to examine the opinions of primary school teachers, individuals with whom students spend the most time through distance education after their families, on children's rights. Participants of this research, adopting one of the qualitative research methods i.e., phenomenology, consist of 19 primary school teachers working in Yozgat, Turkey, determined by purposeful sampling methods. In the research, data were collected through a semi-structured interview form. The data obtained were analyzed using the descriptive analysis technique. As a result of the research, teachers expressed the most opinions about children's right to life, nutrition, and a quality life standard as well as development right to access information. In addition, the most views were on the right of children to participate, on the right to express their opinions freely and on the right to protection from all kinds of maltreatment, neglect, abuse and exploitation. Therefore, teachers' views on children's rights to life, development, participation, and protection were evaluated as negative.

\footnotetext{
*Correspondency: behiyeertas5884@gmail.com
} 


\section{Introduction}

With the spread of Coronavirus Disease (COVID-19) worldwide, it was declared as an epidemic by the World Health Organization on March 12. Due to the epidemic, it has been decided to close schools in many countries in the world and Turkey. One of the main reasons for this decision is that children (Shen et al., 2020) who have the disease with mild or no symptoms effectively spread the virus. Another reason is studies conducted on previous epidemic periods reveal that closing schools are an effective practice in the control of the epidemic (Jackson, Mangtani, Fine, \& Vynnycky, 2014; Rashid, Ridda, \& King, 2015).

Societies form strong structures through healthy individuals. Because an essential element of society is human, and the presence of an individual in the society in a physical, mental, and social sense strengthens the structure of the society (Keskin \& Ögretici, 2013). Children form the core of strong societies. It is possible to see the reflection of the values of a country's education system on children. People who spent their childhood happy and healthy contribute to the well-being of the society in which they live as happy and healthy citizens when they become adults. Therefore, if countries want to live in prosperity, happiness, and peace, they should allocate most of their resources to children's healthy growth and development following their interests and abilities (Akyüz, 2016). Unfortunately, numerous children worldwide are faced with inhumane problems such as hunger, violence, abuse, neglect, homelessness, and exploitation. Keeping children away from these treatments and meeting the basic life needs of every child should be seen as an obligation for countries (Hamberg, 2012). Therefore, the need for legal regulations to protect and keep children away from all kinds of exploitation, neglect, and abuse creates the concept of child rights (Serozan, 2005). In this context, the United Nations Council created the Declaration of the Child's Rights in 1959 to protect children's rights. The obligation to conclude legal agreement to protect children transformed the Declaration of the Rights of Child into the International Convention on the Rights of the Child in 1989 and the Convention on the Rights of the Child reached an international character (United Nations International Children's Emergency Fund [UNICEF], 1998, p.71)

With the announcement of COVID-19 as an epidemic by the World Health Organization, various restrictions have been imposed in countries. Therefore, it can be said that children were deprived of many rights during this epidemic period. For this reason, it is essential to examine the opinions of primary school teachers on children's rights during the COVID-19 epidemic period. It is seen that the classification of the rights included in the Convention on the Rights of the Child takes different forms in the literature (Akyüz, 2016; Franklin, 1993; Fountain, 1993; İnan, 1995; Karaman-Kepenekci, 2010; Tanribilir, 2011). Karaman Kepenekci (2010) classified the child's rights as the right to life, development, participation, and protection in her research. This research evaluated the teachers' opinions by considering this classification. Thus, this research is essential as it is presented. The researchers have not found any studies on teachers' evaluation of children's rights during the epidemic period. It is thought that this research will fill this gap in the literature.

\section{Theoretical Framework}

Children's rights are defined as rights that should be considered for the benefit of the child in order to continue the healthy development of the child in a free and honorable manner in terms of physical, mental, social, emotional, and spiritual aspects within the framework of legal rules (Akyüz, 2016). In other words, children's rights are defined as rights regulated in order to protect and keep children away from all kinds of exploitation, neglect, and abuse. 
Children's rights include several principles for childrens' good life. They are as follows: i) creating suitable conditions for the emotional development of children, ii) providing medical services under all circumstances, iii) the child's self-realization and developing skills appropriate to his abilities, iv) taking an active role in community life, v) being aware of his responsibilities, vi) necessary shelter, food and meeting basic life needs such as education (Nelken, 1998).

For the effective implementation of children's rights in social life, it is necessary to determine common goals, integrate them into state policies, improve education, use the country's resources effectively and efficiently, and increase the effectiveness of the monitoring mechanism. The child can be prepared for life and benefit from social, cultural, and legal rights by improving all children's living standards and health services (Kop \& Tuncel, 2010 p.109). The Declaration of the Rights of the Child, adopted by the United Nations, has been transformed into an international convention and includes the natural and moral relationship between parents and children, parents' responsibilities towards their children, children's rights to their parents, and the state's responsibilities regarding all these rights. In addition, to ensure the quality and integrity of education, education systems are responsible for creating conditions that allow children to learn and practice these rights and reach the competence to exercise these rights as individuals (Allan \& Ianson, 2004). Children should not be seen as the "property" of their parents, and their rights over their children should not be considered unlimited. The state should play a role in the care and protection of children and do all the research that needs to be done about the child to respect the child's best interests (Franklin, 1993). Because a healthy child, living in peace with himself and his environment in the future; a creative, productive, problem solving, effective communication, self-actualized happy adult; he will be a good citizen who knows his rights and responsibilities. The existence of individuals with these characteristics in society is seen as necessary for the development of society (Unutkan, 2008). The individual's existence in society is related to his / her right to life. Therefore, taking away the right to life, which has an important place in children's rights, from the child means taking other rights naturally. The right to life includes the right of the child to live and have a quality life standard, benefit from health services and meet basic human needs such as housing and nutrition. The right to development includes the right to education, play, access to information, cultural activities, rest, freedom of thought, conscience, and religion in order for the child to realize his / her abilities at the highest level. Protection rights consist of the child's rights to be protected from all kinds of maltreatment, neglect, abuse, and exploitation in the legal system, armed conflict, working life, and special care for refugee children. It is based on the best interests of the child. The right to participate enables the child to participate in society. These are the rights that consist of the right to express their opinions, establish an association, assemble freely, and have a say in matters related to them (Akyüz, 2016; Karaman-Kepenekci, 2010).

When the Basic Law of National Education is examined, it is seen that the basic principles of Turkish National Education overlap with the articles in the UNCRC. Education, which is included in the right to development in the UNCRC, is also included in the fundamental law of national education. "Every Turkish citizen has the right to attend primary education. Citizens benefit from educational institutions after primary education institutions to the extent of their interests, talents, and abilities." Therefore, the right to education of individuals is guaranteed by both international and national legislation. In addition, Article 42 of the Constitution of the Republic of Turkey, "No one can be deprived of the right to education," expresses the responsibility of the state to provide the right to education to its citizens. With the principle of equal opportunity, "Equal opportunities are provided to all men and women in 
education." Necessary aids are provided through free boarding, scholarships, loans, and other means to ensure that successful students who lack financial means receive education up to the highest education levels. Special measures are taken to raise children in need of special education and protection." The factors that make up the educational environment may not be the same for every student, but they should be as equal as possible. While preparing education budgets, schools in disadvantaged regions should try to reach the education environment in other schools (Başaran, 1996).

Primary schools are within the scope of compulsory education for four years in Turkey. For this reason, it is also essential that the objectives of primary education have been achieved in line with the UNCRC and the objectives of the Turkish National Education. According to the objectives of primary education, "To provide every Turkish child with the basic knowledge, skills, behaviors, and habits necessary to be a good citizen; to raise him by the national morality; to prepare every Turkish child for life and higher education by raising them in terms of their interests, talents, and abilities. In this context, children who start school find themselves in a new and comprehensive social environment for the first time after the family. Children develop social relations by establishing close relationships with their teachers and friends. The primary school period is necessary for developing peer relationships and communication. In addition, the right to participate in this period has an essential role in the child's healthy development. Children do not show their full potential and cannot develop in environments where everything is ready for them; they remain passive and cannot intervene and change. When children participate in social life, feelings of ownership and responsibility, self-confidence, and self-worth develop (Erbay, 2016).

Economic, technological, and environmental conditions that change over time determine and change the social life of children and cause children to experience their daily lives differently. Therefore, the child's legal status, economic aspect, social roles, status, and agency may change depending on the changing conditions (Güçlü, 2016). Children's experiences have also changed due to the changing living conditions with the COVID-19 epidemic. Students' learning, behavioral changes, and better performance at school depend on establishing common goals with collaborative, complementary, and supportive relationships in the home, school, and society where children live (Epstein, 2011; Blandford, 2003). According to Lightfoot (1978), the balance between school and home environment is different from each other. For the healthy development of children, it is necessary to establish bonds that can provide this balance, to explore the differences in socialization and teaching practices between school and home (Lightfoot, 1978). However, the process of the COVID-19 pandemic has prevented the family, school, and society from establishing cooperative and supportive relationships. Therefore, when discussing children's rights, it is necessary not to ignore them with different needs and develop a holistic perspective on all children (Alderson, 2008). Thus, raising children who guarantee the future as individuals exercising their rights will become a critical situation for society and humanity.

While discussing children's rights, it is essential not to ignore their different needs and develop a holistic perspective regarding all children (Alderson, 2008). Thus, the growth of children, who are the guarantors of the future, as individuals exercising their rights will become a problematic situation for society and the whole of humanity. 


\section{Method}

This heading includes the research model, participants, data collection tools, analysis, credibility, and ethics.

\section{Research Model}

This research was designed with qualitative research based on the views of primary school teachers on children's rights in the COVID-19 distance education process. Arguably, persons both shape the social system they live in as subjects and are changed by the social system as objects. Qualitative research endeavor is thereupon seen as an effort to process factual information with an inductive method, with the idea that studies on understanding human and social phenomena that humans exist within and beyond require in depth exploration. In qualitative research, reality may require interpretation within the very social environment (S1ğrı, 2021). Therefore, in this research, the views of primary school teachers on children's rights during the epidemic were examined in-depth and a phenomenological approach from qualitative designs was adopted. The phenomenological design focuses on the phenomena that are defined and realized in terms of the experiences of individuals or a particular group but cannot have a detailed and in-depth understanding (Sığrı, 2021; Y1ldırım \& Şimşek, 2016). It is aimed to describe the experiences of individuals who have different experiences in studies created with a phenomenological design (Creswell, 2014). Phenomenological studies reveal how the participants feel, think and perceive their experiences in their lives and how they create a state of consciousness by structuring them (Patton, 2002). In phenomenological studies, individuals' interpretation of experiences and their transformation into consciousness as both individual and shared meaning are examined with a profound description (Patton, 2014). The phenomenological design is handled with two different approaches: interpretative phenomenology and descriptive phenomenology (VanManen, 1990; Shosha, 2012). The descriptive phenomenology approach was used in the research as it was aimed to reveal the perceptions and experiences of the participants regarding children's rights (Ersoy, 2018).

\section{Study group}

Nineteen primary school teachers working in Yozgat constitute the research study group. Criterion and appropriate case sampling methods, among purposeful sampling methods, were used in sampling selection. In research, observation units may consist of people, objects, events, or situations with certain qualities, and in this case, units that meet the criteria set for the sampling are included in the sampling (Büyüköztürk, Çakmak, Akgün, Karadeniz, \& Demirel, 2020). The appropriate case sampling is about the easy inclusion or accessibility of the participants to the research process (Ekiz, 2015). Therefore, the primary school teachers who carry out the distance education activities were determined as criteria in this research. The criteria sampling was used, and the appropriate case is sampling to provide speed, time, and practicality to the researchers. Demographic information about the study group is presented in Table 1. 
Table 1. Demographic information regarding the study group

\begin{tabular}{lll}
\hline & & Frequency $(\mathrm{f})$ \\
\hline Gender & Female & 8 \\
& Male & 11 \\
\hline Education Status & Bachelor degree & 12 \\
& Master's degree & 7 \\
\hline Professional experience & $1-5$ years & 6 \\
& $6-10$ years & 7 \\
& $11-15$ years & 5 \\
& $16-20$ years & 1 \\
\hline
\end{tabular}

When Table 1 is examined, 8 of the teachers participating in the research are female, and 11 are male. Seven of the teachers are master's degrees, 12 are bachelor's degrees, and their professional experience is between 3 and 17. In addition, 6 of the teachers have $1-5$ years, 7 of them 6 - 10 years, 5 of them $11-15$ years, and 1 of the $16-20$ years of professional experience.

\section{Data Collection Tools and Data Collection}

In the research, a semi-structured interview form prepared by the researchers and expert opinion (5 experts) was used to ensure that primary school teachers' perceptions regarding children's rights in the COVID-19 distance education process are explained with their thoughts (Merriam, 2013). Since the interview technique in qualitative research is essential to understand the meanings, feelings, and thoughts of the participants and to obtain more in-depth information, unlike quantitative interviews, data were collected with the interview technique in this research (Cemaloğlu, 2012). It is aimed to examine the participants' views on children's rights in detail. While creating the interview questions, a literature review was done; it has been observed that there is no research on the views of primary school teachers on children's rights in the COVID-19 distance education process. It is seen that the Convention on the Rights of the Child, adopted by the United Nations General Assembly on November 20, 1989, is classified differently (Franklin, 1993; İnan, 1995; Tanribilir, 2011; Fountain, 1993). The questions in the interview form were prepared by the researchers considering the classification of the right to life, the right to development, the right to participate and the right to protection, and as a result of the interviews with the primary school teachers who were outside the scope of the study group. After the researchers prepared the interview form, expert opinions were obtained from two faculty members and three primary school teachers to ensure face validity, and opinions were received from two Turkish teachers about spelling and punctuation, and the form was given its final form. In order to test the clarity of the finalized interview form, preliminary interviews were conducted with three primary school teachers who were not included in the study group. Incomprehensible interview questions were structured, and the interview form was given its final form.

Necessary legal permissions were obtained from the ethics committee of Yozgat Bozok University and Yozgat Provincial Directorate of National Education in Turkey to collect data in the research. Interviews were held with the research study group, and data were collected. The interviews were made in audio and video calls and recorded with a voice recorder. Few participants did not accept the interview due to a voice recorder and stated that they answered the form via e-mail. Short interviews were held with the participants for the data collected by mail, and the interviews were ended by asking if they had anything to add.

Researchers set aside what they knew about their individual experience and work and focused 
only on what the participants said and wanted to get in-depth information. Therefore, researchers tried to reveal teachers' perceptions of children's rights during the epidemic process with their role as information seekers (Glesne, 2020) and assumed the role of the learner in the research. Thus, there is no conflict of interest between the researchers.

The phenomenological interview process is a communication and interaction process, and both the researcher and the participant are active elements of this process. In order to gather the speeches of the participants at a certain point and to ensure their focus, the interview is held within the scope of the questions determined by the researchers (Ersoy, 2019). The researchers collected data through interviews with teachers because they had difficulty reaching the participants due to the epidemic. In addition, the primary purpose of the research is to create the research data by the answers to the questions determined by the researchers within the scope of examining children's rights according to teachers' opinions in the COVID19 epidemic.

\section{Data Analysis}

The descriptive analysis technique was used to analyze the data obtained through phenomenological interviews. Descriptive analysis can be provided by directly giving the verbal data obtained in the relevant research questions to find answers to the research questions. In the descriptive analysis, themes and codes are determined beforehand and looked at within the data (Sığrı, 2021). In the research, each of the rights classified as the right to life, the right to development, participation, and protection were handled as a theme. The participants' answers for each question in the interview form were predetermined as a theme, and the statements were divided into sub-themes and interpreted. In the process of analyzing the data, different codes were created by each researcher as "positive" and "negative" according to the sub-categories of the teachers' opinions, and then the codes were compared by the researchers together, and a consensus was reached in cases where there was a difference of opinion. The purpose of the descriptions in qualitative research is to create a text that reflects the participants' viewpoints whose data is collected and conveys the ordinary details in daily life. In the descriptive analysis, researchers mainly quote directly from the participants' statements (Yıldırım \& Şimşek, 2016). In the current research, the researchers used the expressions of the participants as much as possible without changing them and presented them to the reader. Since the researchers aimed to present and describe the situation, the statements obtained from the interviews were presented to the reader with long quotations. The names of the participants were coded as $T_{1}, T_{2}, T_{3}, \ldots T_{19}$ both during the data collection phase and in the analysis and presentation of the data.

\section{Credibility and Reliability of the Research}

Care was taken to ensure validity and reliability in the study. First of all, after the researchers prepared the interview form, expert opinions were obtained from two lecturers and three primary school teachers to ensure face validity, opinions were received from two Turkish teachers about spelling and punctuation, and the form was given its final form. In order to test the intelligibility of the finalized interview form, preliminary interviews were conducted with three primary school teachers who were not included in the study group. Incomprehensible interview questions were structured, and the interview form was given its final form. In order to increase the reliability of the interviews, the data obtained were confirmed in the interviews with the participants and progressed. The credibility criterion is the preparation of the semi-structured interview form by taking expert opinion, the voluntary participation of the participants in the research, and the voice recordings with their 
permission; the transferability criterion with the method of transferring the data by being faithful to its nature and choosing a purposeful and easily accessible sample; The consistency criterion was provided by the researchers working together in the process from the creation of the data collection tool to the data analysis. In order to ensure the confirmability criterion, each of the researchers first made their evaluations and then worked on the raw data together to examine whether the judgments they reached were similar and if the results arrived at matched. Then, the consensus was achieved by discussing the conflicting results (Y1ldirım \& Şimşek, 2016).

\section{Ethical Considerations}

Necessary legal permissions were obtained from the ethics committee of Yozgat Bozok University and Yozgat Provincial Directorate of National Education to collect data in the research. The purpose of the research was explained to the participants in the study group, the rights of the participants and the confidentiality of the data were mentioned. Finally, the participant signed the written consent form. It has been stated that the right of a participant who wishes to withdraw from the research will be respected, the data collected about him will be returned to him, and the information found in the researchers will be destroyed (Miles \& Huberman, 1994). Since it is crucial to protect participant confidentiality and keep the data meticulously, a code name was used for each participant, considering that third parties could obtain the data while collecting and storing it. There is no conflict of interest between the researchers.

\section{Results}

This section includes the findings resulting from the analysis of teachers' views on children's rights during the COVID-19 epidemic period. The findings were collected under the titles of right to life, right to development, right to participate and protection rights and sub-headings related to these headings. In addition, the findings were supported by direct quotations from teachers' opinions.

\section{Teachers' Views on Children's Right to Life During the COVID-19 Epidemic Period}

During the COVID-19 epidemic, teachers' views on children's right to life are under the central theme of "right to life"; They were gathered under the sub-themes of "nutrition, a quality living standard, benefiting from health services and sheltering." The findings obtained by the data obtained from the participant opinions are presented in Table 2.

Table 2. Teacher's Views on Children's Right to Life

\begin{tabular}{|c|c|c|c|c|}
\hline Theme & Sub-Theme & View Type & Teachers & $\mathrm{f}$ \\
\hline \multirow{4}{*}{ 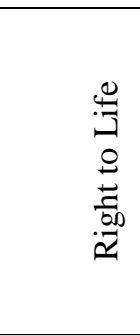 } & Nutrition & $\begin{array}{l}\text { Positive } \\
\text { Negative }\end{array}$ & $\mathrm{T}_{1,2,3,5,6,8,9,10,11,13,14,16,17,19}$ & 14 \\
\hline & A quality standard of living & $\begin{array}{l}\text { Positive } \\
\text { Negative }\end{array}$ & $\begin{array}{l}\mathrm{T}_{4} \\
\mathrm{~T}_{1,2,5,6,8,9,10,11,13,14,16,17,19}\end{array}$ & $\begin{array}{l}1 \\
13 \\
\end{array}$ \\
\hline & Benefiting from Health Services & $\begin{array}{l}\text { Positive } \\
\text { Negative }\end{array}$ & $\mathrm{T}_{2,4,5,6,8,9,10,11,13,14,17,19}$ & 12 \\
\hline & Housing status & $\begin{array}{l}\text { Positive } \\
\text { Negative }\end{array}$ & $\begin{array}{l}\mathrm{T}_{4} \\
\mathrm{~T}_{2,5,8,10,13,14,19}\end{array}$ & $\begin{array}{l}1 \\
7\end{array}$ \\
\hline
\end{tabular}

When the teachers' views on children's right to life are examined according to Table 2 , it is seen that most of the teachers express their opinions about children's right to nutrition ( $f=14$ ) and a quality living standard $(\mathrm{f}=14)$. In addition, 12 teachers gave their opinions about the right of children to benefit from health services, while eight teachers made opinions about the 
right to housing. When the opinions of the teachers were examined, only T4's views on the children's right to a quality living standard and housing were evaluated as positive, while the opinions of the teachers about the other rights of the children were evaluated as negative. Therefore, based on the observations and experiences of teachers, it can be said that they have a negative opinion about the basic right to life of children. Since the epidemic process affects the economic conditions of families, it is thought that this situation negatively affects the basic right to life of children. Some of the teachers' views on children's right to life are as follows:

$\mathrm{T}_{17}$ : Children were the group most affected by the Covid 19 outbreak. Children, who learned life through interaction and play, were removed from the playgrounds and streets during this period due to the prohibitions pertaining to the epidemic. Switching to a monotonous life mode, while they should have been in the most interaction with their environment, has reduced children's living standards. Apart from this, our diet changed during the epidemic and prohibition period, and unhealthy diets were taken up. Because the children are constantly kept indoors, some developed anorexia and some others obesity. As for other health related issues, hospitals cannot be controlled easily due to the risk of contamination of the virus everywhere and the ministry of health is asking us not to go to hospitals unless it is an emergency, hospitals where the risk of the virus spreading is the most dangerous for children. In this case, families first try to solve their children's health problems themselves. They prefer to go to the hospital under challenging situations.

$\mathrm{T}_{8}$ : I think health services and quality living rights could not be met during the epidemic. Hospitals refused their outpatient services when there was no emergency. The kidney filter width problem that my child has been experiencing since the womb had to be followed up every 3 months, and an ultrasound should be performed. Doctors didn't do it because of the pandemic. They said they could not do it until the pandemic was over unless there was an emergency. Like health, I think that children's rights to a quality life couldn't be met. The quality of life of children couldn't be assured due to pandemic constraints on games and the activities they do with their friends and family.

$\mathrm{T}_{11}$ : The institution I work for covers an environment with families with low economic status. The children living in this area are below the standards, especially nutrition wise. Due to our work in this environment, we determined that many families were experiencing food shortages, and we helped them as an institution. We tried to reduce many deficiencies by helping each other. We have seen that families, especially children, do not have quality nutrition during this process, even though they are not hungry for nourishment. In terms of health, I do not think there is any problem with institutional facilities in our country. Still, families are worried about taking their children to hospitals. Health checks are interrupted due to the pandemic. It might have been more beneficial if hospitals working only for children were arranged.

\section{Teachers' Views on Children's Right to Development During the COVID-19 Epidemic Period}

During the COVID-19 epidemic, teachers' views on children's right to development are in the central theme of "right to development." They were gathered under the sub-themes of "access to information, education, cultural activities, freedom of thought, conscience and religion, rest." The findings obtained by the data obtained from the participant opinions are presented in Table 3. The results obtained by the data obtained from the participant opinions are shown in Table 3. 
Table 3. Teacher's Views on Children's Right to Development

\begin{tabular}{|c|c|c|c|c|}
\hline Theme & Sub-Themes & View Type & Teachers & $\mathrm{f}$ \\
\hline \multirow{9}{*}{ 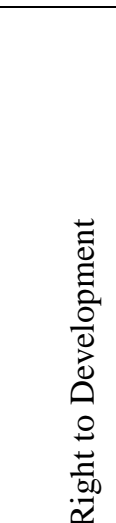 } & \multirow{2}{*}{ Access to Information } & Positive & $\mathrm{T}_{7,9,15}$ & 3 \\
\hline & & Negative & $\mathrm{T}_{1,2,4,5,6,8,10,11,12,13,14,17,18,19}$ & 14 \\
\hline & \multirow[b]{2}{*}{ Education } & Positive & $\mathrm{T}_{7}$ & 1 \\
\hline & & Negative & $\mathrm{T}_{1,2,3,4,5,6,8,10,11,12,13,14,17,18,19}$ & 15 \\
\hline & \multirow{2}{*}{ Cultural Activities } & Positive & $\mathrm{T}_{7}$ & 1 \\
\hline & & Negative & $\mathrm{T}_{3,5,6,8,10,11,14,15,17,19}$ & 10 \\
\hline & Thought & $\begin{array}{l}\text { Positive } \\
\text { Negative }\end{array}$ & $\mathrm{T}_{2,3,4,5,9,11,15,17,19}$ & 9 \\
\hline & $\begin{array}{l}\text { Freedom of Conscience and } \\
\text { Religion }\end{array}$ & $\begin{array}{l}\text { Positive } \\
\text { Negative }\end{array}$ & $\mathrm{T}_{2,9,12,17,19}$ & 5 \\
\hline & Rest & $\begin{array}{l}\text { Positive } \\
\text { Negative }\end{array}$ & $\mathrm{T}_{17,19}$ & 2 \\
\hline
\end{tabular}

According to Table 3, teachers' views on children's right to development are examined, most of the teachers stated their views on children's rights to access information ( $f=17$ ), education ( $f=16$ ) and cultural activity $(\mathrm{f}=11)$. Apart from these rights, the teachers; 9 of them had opinions, 5 of them on freedom of conscience and religion, and 2 of them on the right to rest. When the teachers' views were examined about the children's rights to access information ( $\mathrm{f}=$ 3 ), education $(f=1)$, and cultural activity $(f=1)$ were evaluated as positive. However, their opinions about the other rights of the students were also assessed as negative opinions. Therefore, it can be said that teachers' views on children's right to development are mostly negative. In addition, it can be said that providing children with access to information, usually through distance education, affects the social, cultural, and economic lives of families. In addition, it is thought that the emotions, thoughts, and mental states of children are also affected by this epidemic period and this situation negatively affects their right to development. Some of the teachers' views on children's right to development are as follows:

$\mathrm{T}_{4}$ : Access to information is much easier now. However, is it the data itself what we need? It is much more important to use knowledge, make inferences by using it, criticize, interpret, and learn by doing and living. The epidemic deprived children of these. Much remained at the level of knowledge, whether in live lessons or face-to-face school. We could not pass the children to the next step. Unfortunately, we will see the shortcomings of this in the coming years.

$\mathrm{T}_{17}: \ldots$ children both have fun and learn while playing. However, being detached from the play environment and being alone at home means being deprived of values such as fairness, sharing, and affection for help. Especially because families working from home cannot take care of their children as desired, it lags behind many things. At the same time, the transition of educational activities to distance education prevents children from receiving education freely. In addition, the lack of equipment and net has affected the students' success.

In contrast, the students have had less interaction and less concentration on the lessons than face-to-face education. Because face-to-face activities, games, drama, and art contribute to children's sharing their thoughts, empathizing, and thinking. Unfortunately, because they are deprived of these, children have problems accessing information. They cannot find a medium to express themselves in terms of freedom of thought, listening, conscience and religion. These happen because families are also tired of being at home all the time. Therefore, they are not fully concerned with the education and development of their children.

$\mathrm{T}_{19}$ : All cultural activities are currently stopped. A break was given, but the families did not want to send their children to school? because they did not want to? attend. There was 
a time when they could not develop themselves culturally. Our cultural activities, namely our weddings, henna nights, festivities, festivals ... children were deprived of these as they were amongst the factors that accelerated the increase of the epidemic. Cultural activities can, of course, be explained to children. Still, by participating in these activities that belong to our culture, their learning will always be more permanent. Children exercise their right to rest, but I do not believe short rest periods of 10 minutes between live lessons are sufficient. I observed that they could not sleep, and that the efficiency of the training decreased. We know that children's ideas are not taken at all during this process regarding freedom of thought.

Schools will be opened. OK. Schools will be on vacation. OK. Live lessons will be delivered at this time on the following days. OK. These are the hours to go out. OK. They were always told the rules they had to obey. This situation appeared as a factor that eroded their mental perceptions and made them angrier. It should not be easy for them to live the consequences of the decisions they are not always involved in, while 'life does not fit home' for them anyway. ('Life fit home' is the motto of'life fit home' the Ministry of Health during lockdowns). Regarding freedom of religion and conscience, I am not talking about changing faith but living, collective worship. Since mosques and mass worship are prohibited due to the pandemic, children are deprived of these rights like everyone else.

\section{Teachers' Views Regarding Children's Right to Participation During the COVID-19 Epidemic Period}

During the COVID-19 epidemic, teachers' views on children's right to participate are in the central theme of "the right to participate." They were grouped under the sub-themes of "being able to express their opinions freely and have a say in matters related to themselves." The findings obtained by analyzing the data obtained from the participant opinions are presented in Table 4.

Table 4. Teachers' Views on Children's Right to Participation

\begin{tabular}{|c|c|c|c|c|}
\hline Theme & Sub-Themes & View Type & Teachers & $\mathrm{f}$ \\
\hline 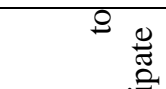 & Expressing Thoughts Freedom & $\begin{array}{l}\text { Positive } \\
\text { Negative }\end{array}$ & $\begin{array}{l}\mathrm{T}_{7,12,17} \\
\mathrm{~T}_{1,2,3,4,5,6,10,11,13,14,18,19}\end{array}$ & $\begin{array}{l}3 \\
12\end{array}$ \\
\hline 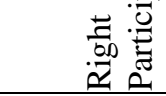 & $\begin{array}{l}\text { To have a say in matters affecting } \\
\text { their own lives }\end{array}$ & $\begin{array}{l}\text { Positive } \\
\text { Negative }\end{array}$ & $\begin{array}{l}\mathrm{T}_{7,8,17} \\
\mathrm{~T}_{4,5}\end{array}$ & $\begin{array}{l}3 \\
2\end{array}$ \\
\hline
\end{tabular}

According to Table 4, when the teachers' opinions on the children's right to participate are examined, the majority of teachers have stated their views on children's right to express their opinions freely $(f=15)$, and five teachers have stated their right to have a say in matters related to them $(f=5)$. When the teachers' opinions were examined, the views of three teachers $\left(\mathrm{T}_{7,12,17}\right)$ regarding the right to express their opinions freely were evaluated as positive. In comparison, the views of three teachers $\left(\mathrm{T}_{7,8,17}\right)$ about the right to have a say in matters related to them were positive, and two teachers $\left(\mathrm{T}_{4,5}\right)$ were evaluated as a negative opinion. Although teachers express a small number of opinions about the right of children to have a say in matters related to them, which are within the scope of children's right to participate, the evaluation of most of these opinions as positive opinions can be expressed as an indicator that teachers use this right by children. Some of the teachers' views on children's right to participate are as follows:

$\mathrm{T}_{11}$ : I think the participation rights of students are limited only within the family in this regard. Especially during the distance education process, it is evident that they are confused due to the curfews at home and during the remaining lessons. The lack of 
socialization of students with limited time spent outside caused them to be inadequate in expressing themselves. My students were incapable of expressing themselves. The main reason for this is the lack of socialization and decreased interaction within the family, especially during the pandemic period. I think that children who cannot express themselves will not exercise their right to participate. As I said at the beginning, it can only be limited within the family. The room can take place in conscious families that care about children's views. Unfortunately, I think these families are very few in our society.

$\mathrm{T}_{19}$ : I can add the following to what I said in the previous question on this issue: Children did not have any right to participate in the decisions taken for children during the COVID-19 epidemic period. Could the reverse be possible? It is open to discussion. However, we, as teachers, had to prepare the ground for children to express their thoughts freely in this process. We could change a lot of things with the children's participation, such as the time when the lessons started, when the classes ended, the rest periods, the time to go out. We could change many things with the children's participation in the decision-making processes, but this time the life of the teachers was ignored. To say it for me, I talked about all of these with my students. We tried to come to a joint decision (re. the start time of the lesson, rest breaks, end time of the task, the number of assignments accordingly, etc.) Howbeit, we still chose the one that suits me better Due to many reasons, like my baby's being tiny, the caregiver leaving after a particular hour. Suppose I were not a teacher with a baby. In that case, I am sure I would have continued this process by paying more attention to the participation rights of my students.

\section{Teachers' Views on the Right to Protection of Children in the COVID-19 Epidemic Period}

During the COVID-19 epidemic, teachers' views on children's right to protection are in the central theme of "right to protection"; it has been gathered under the sub-themes of "protection from all kinds of ill-treatment, neglect, abuse and exploitation and observing the best interests." The findings obtained by analyzing the data obtained from the participant opinions are presented in Table 5.

Table 5. Teacher's Views on Children's Right to Protection

\begin{tabular}{cllll}
\hline Theme & Sub-Themes & View Type & Teachers & $\mathrm{f}$ \\
\hline Protection from all kinds of Positive & $\mathrm{T}_{7,8}$ & 2 \\
& $\begin{array}{l}\text { maltreatment, neglect, abuse, and Negative } \\
\text { exploitation }\end{array}$ & $\mathrm{T}_{9,10,11,13,14,15,16,17,19}$ & 9 \\
\cline { 2 - 3 } & $\begin{array}{l}\text { The best interests of the child being } \\
\text { the primary consideration }\end{array}$ & $\begin{array}{l}\text { Positive } \\
\text { Negative }\end{array}$ & $\mathrm{T}_{9,13,14,17,19}$ & 5 \\
\hline
\end{tabular}

According to Table 5, when the teachers' views on the right to protection of children are examined, the majority of teachers have the opinion on children's right to be protected from all kinds of maltreatment, neglect, abuse and exploitation ( $f=11)$, and five teachers have the right to protect children's best interests $(f=5)$. They stated. When the teachers' opinions were examined, the opinions of two teachers $\left(\mathrm{T}_{7,8}\right)$ about the children's right to be protected from all kinds of maltreatment, neglect, abuse, and exploitation were evaluated as positive. In addition, all of the teachers' opinions about the right to protect the best interests of children were evaluated as negative opinions. It can be said that teachers generally have a negative view of children's right to protection during epidemic periods. Some of the teachers' views on children's right to protection are as follows: 
$\mathrm{T}_{9}$ : An essential detail regarding the observance of protection rights caught my attention. My attention was drawn to the participation of 1st-grade students' parents in the lessons I spent six days a week. Families inflict psychological violence on children even during the learning phase. This happens even when there are teachers and students in the learning environment. Sometimes this can even turn into physical violence. In addition, family members pay the children for their negativities due to the conditions in the epidemic process. Moreover, for this reason, we can easily see unhappy children even while doing the learning work.

$\mathrm{T}_{16}$ : Negative conflicts within the family can also affect children. While the family must behave meticulously in this process, unfortunately, children can be neglected. Children are also negatively affected by the damage COVID-19 has caused in the society in general. Unfortunately, children may encounter negative behaviors, as schools are not the primary places for students anymore to spend their days.

$\mathrm{T}_{14}$ : Some families who had to be confined to the house during the epidemic period had a large family structure. Suppose the physical environment of such families, i.e., their living spaces, is insufficient or small. In that case, family members inevitably cause each other's private lives to be neglected and restrict each other's personal lives. In private life interventions such as this, children will likely be subject to privacy negligence. Furthermore, witnessing unwanted home situations of individuals sharing the same environment may create traumas, emotional turmoil, and conditions that they cannot understand and accept in their minds due to their age.

\section{Conclusion, Discussion and Suggestions}

The findings obtained from this research were discussed with the relevant literature findings, and the results were presented.

It was concluded that during the epidemic period, teachers expressed the most opinions about nutrition and a quality living standard included in the children's right to life, and these views were mainly considered negative opinions. In addition, it was observed that teachers had a negative view of children's right to health and housing during the COVID-19 epidemic period. During the epidemic, children consume less fruit and vegetables and reach healthy meals less (Josephson et al., 2021; Patrick et al., 2020; Tar \& Atik, 2021), and they face childhood obesity (An, 2020; Pietrabissa et al., 2021; Couper-Kenney \& Riddell, 2021), Type-1 diabetes in children has increased due to lifestyle changes (Brener et al., 2020), depending on the education and income level of the family. Moreover, they live in homes with irregular working environments (Thomeer, Yahirun, \& Colón-López, 2020), crowded and inadequate home environments increase the risk of COVID-19 and infectious diseases in children (Freedson, 2021; Suleman et al., 2020). Westrupp et al. (2021), in the research of low-income families; It was found that while working from home, they had difficulties in providing care to children due to financial insufficiency. Wanyana, Wong and Hakizimana (2021) due to the COVID-19 pandemic, families cannot benefit from health services adequately due to fear of getting the virus, economic and social reasons, and children with special needs (Rogers et al., 2021; Sardohan-Yıldırım \& Bozak, 2021) has been reached. Children who are financially and morally supported (for example, parents who can work from home, who live in a safe place, who are given care for their children, have access to the internet, and have the opportunity to shop online) benefit more from the fundamental right to life (Palkovitz \& Fagan, 2021).

It was observed that most teachers expressed their views on the right to access information 
and education rights. It was concluded that a small part of the teachers had a positive opinion about the rights of children during the COVID-19 epidemic period, but a significant majority expressed a negative opinion about this process. In addition, it was concluded that teachers have more negative views on cultural activities, freedom of thought, conscience and religion, and right to rest, which are within the scope of children's right to develop. Furthermore, when the literature is examined, it is seen that there is a significant learning loss during the epidemic process (Saavedra, 2020; Armitage \& Nellums, 2020), significant inequality in access to the education process (Misirli \& Ergulec, 2021; Saran, 2020) and access to remote access equipment is challenging, especially in households with low economic indicators (Armitage \& Nellums, 2020; Daniel, 2020; Freedson, 2021; Gelber, Castillo, Alarcón, Treviño, \& Escribano, 2021; Couper-Kenney \& Riddell, 2021), as well as limited recreation and education support for children with special needs. Alternatively, not at all (Rogers et al., 2021), children's play dates with friends, and doing other favorite routine activities, sports and music courses (Misirli \& Ergulec, 2021; Choi et al., 2021; Larsen, Helland, \& Holt, 2021; UNICEF, 2020; Wang, Zhang, Zhao, Zhang, \& Jiang 2020).

It was found that the majority of the teachers expressed their views on the right of children to express their opinions freely and that their opinions were evaluated more negatively. In addition, although it is seen that children express biased opinions about having a say in matters related to them, most of these views are evaluated as positive. Therefore, it can be said that teachers believe that children use this right. However, when the literature is reviewed, with the depression that increases with the epidemic, the communication between parents and children is negatively affected (Chung, Lanier, \& Wong, 2020; Connell \& Strambler, 2021; Feinberg et al., 2021; Palkovitz \& Fagan, 2021; Patrick et al., 2020 ), with children having difficulty in obtaining information due to the information confusion during the epidemic process (González, Evangelista, \& Espinosa, 2021), restricting their views freely (Cuevas-Parra, 2021; Dulieu \& Burgess, 2020; Freedson, 2021), it has been concluded that the right of participation of their children has also decreased.

Most of the teachers expressed the most opinions about children's right to be protected from all kinds of maltreatment, neglect, abuse, and exploitation. It was found that the teachers also had a more negative opinion. They also gave a completely negative opinion about the child's best interests. With the epidemic, school closure, especially girls' dropping out of school, getting married at an early age, and being sexually abused (Freedson, 2021; Haddad et al., 2020; Plan International, 2021; UNICEF, 2020) and child labor has increased with the increase of time spent outside of school (World Bank, 2020; Freedson, 2021; Smith \& Ndeda, 2021; UNICEF, 2020), where children lose access to safe environments with increasing domestic violence (Freedson, 2021; Prime, Wade \& Browne, 2020; Hoyos \& Saavedra, 2021), research results have been achieved.

\section{Recommendation}

Based on the research findings, it can be said that children's rights were violated during the COVID-19 pandemic. Based on all the findings, it is seen that children's rights are a social problem both in the epidemic and in the normal life process. Researchers and policymakers should view the COVID-19 outbreak as learning to prevent the effects of further crises. Researchers may be advised to conduct detailed research to reduce the devastating effects of future crises with new legal regulations. Furthermore, international plans and interventions are needed to improve individuals' socio-economic conditions and solve the financial problems caused by unemployment in times of crisis. It is recommended to establish crisis 
funds to relieve individuals financially in times of crisis and provide assistance to families with low socio-economic levels until the crisis and the impact of the crisis pass. Thus, the education deficits of children who cannot access opportunities, especially in times of crisis, can be tried to be closed to some extent.

In addition, there is a need for early intervention programs for families and their children who are both socially and psychologically affected by the epidemic period. It is recommended to cooperate with experts at the ministry level to meet the educational needs of families, such as childcare and home activities that they can do with their children. Children do not show their full potential and cannot develop in environments where everything is ready for them; they remain passive and cannot intervene and change. Therefore, the active role of children in social life depends on knowing and exercising their rights. Online training, books, brochures, etc., to take more concrete steps on children's rights. It is recommended to raise awareness of families with resources such as children's rights and provide training to all individuals living in the society. Children, who are the guarantee of our future, live by knowing their rights and obtaining their rights; It is thought that it will result in them growing up as free, selfexpressive individuals who take responsibility for their present and future lives. Therefore, it can be said that there is a need for studies by researchers to make children and adults adopt children's rights. It is recommended to conduct new research on children's rights related to different age groups.

\section{References}

Akyüz, E. (2016). Çocuk hukuku: Çocukların haklarl ve korunması [Children's law: Children's rights and protection]. Pegem

Alderson, P. (2008). Young children's rights: Exploring beliefs. Jessica Kingsley Publishers.

Allan, J., \& I'Anson, J. (2004). Children's rights in school: power, assemblies and assemblages. The International Journal of Children's Rights, 12, 123-138.

An, R. (2020). Projecting the impact of the coronavirus disease-2019 pandemic on childhood obesity in the United States: A microsimulation model. Journal of Sport and Health Science, 9(4), 302-312. https://doi.org/10.1016/j.jshs.2020.05.006

Armitage, R., \& Nellums, L. B. (2020). Considering inequalities in the school closure response to COVID-19. The Lancet Global Health, 8(5), e644. https://doi.org/10.1016/S2214-109X(20)30116-9.

Başaran, İ.E. (1996). Ĕ̈itim yönetimi. [Educational management]. Kadığlu.

Blandford, S. (2003). Managing discipline in schools. Routledge.

Brener, A., Mazor-Aronovitch, K., Rachmiel, M., Levek, N., Barash, G., Pinhas-Hamiel, O., Lebenthal, Y., \& Landau, Z. (2020) Lessons learned from the continuous glucose monitoring metrics in pediatric patients with type 1 diabetes under COVID-19 lockdown. Acta Diabetol 57, 1511-1517.

Brown, S. M., Doom, J. R., Lechuga-Peña, S., Watamura, S. E., \& Koppels, T. (2020). Stress and parenting during the global COVID-19 pandemic. Child abuse \& neglect, 110, (2), 104699. https://doi.org/10.1016/j.chiabu.2020.104699.

Büyüköztürk, Ş., Çakmak, E. K., Akgün, Ö. E., Karadeniz, Ş., \& Demirel, F. (2020). Bilimsel araştırma yöntemleri [Scientific research methods]. Pegem.

Cemaloğlu, N. (2012). Veri toplama teknikleri: Nicel-nitel. [Data collection techniques: Quantitative-qualitative]. A. Tanrı̈̈̆gen (Ed). Bilimsel araştırma yöntemleri. [Scientific research methods]. (pp.133-164). An1.

Choi J, Park Y, Kim H-E, Song J, Lee D, Lee E, Kang H, Lee J, Park J, Lee J-W, Ye S, Lee S, Ryu S, Kim Y, Kim Y-R, Kim Y-J,, \& Lee Y. (2021). Daily Life Changes and Life 
Satisfaction among Korean School-Aged Children in the COVID-19 Pandemic. International Journal of Environmental Research and Public Health, 18(6):3324. https://doi.org/10.3390/ijerph18063324

Chung, G., Lanier, P., \& Wong, P.Y.J. (2020). Mediating effects of parental stress on harsh parenting and parent-child relationship during Coronavirus (COVID-19) pandemic in Singapore. Journal of family violence, 1-12. Advance online publication. https://doi.org/10.1007/s10896-020-00200-1

Connell, C. M., \& Strambler, M. J. (2021). Experiences with COVID-19 stressors and parents' use of neglectful, harsh, and positive parenting practices in the Northeastern United States. Child maltreatment,26(3), 255-266.

Couper-Kenney, F., \& Riddell, S. (2021). The impact of COVID-19 children with additional support needs and disabilities in Scotland. European Journal of Special Needs Education, 36(1), 20-34, DOI: 10.1080/08856257.2021.1872844

Creswell, J. W. (2019). Educational research; planning, conducting and evaluating quantitative and qualitative research. Edam.

Cuevas-Parra, P. (2021). Thirty years after the UNCRC: children and young people's participation continues to struggle in a COVID-19 world, Journal of Social Welfare and Family Law, 43(1), 81-98, DOI: 10.1080/09649069.2021.1876309

Daniel S. J. (2020). Education and the COVID-19 pandemic. Prospects, 1-6. Advance online publication. https://doi.org/10.1007/s11125-020-09464-3

Dulieu, N., \& Burgess, M. (2020). The hidden impact of COVID-19 on Child Rights. Save the Children International.

Ekiz, D. (2015). Bilimsel araştırma yöntemleri. [Scientific research methods]. An1.

Epstein, J. L. (2011). School, family, and community partnerships: Preparing educators and improving schools. Westview.

Ersoy, A. (2018). Fenomenoloji [Phenomenology]. An1.

Ersoy, F. (2019). Fenomenoloji [Phenomenology]. A. Saban \& A. Ersoy (Eds). Eğitimde nitel araştırma desenleri [Qualitative research designs in education]. (pp. 81-134). An1

Feinberg, M. E., A Mogle, J., Lee, J. K., Tornello, S. L., Hostetler, M. L., Cifelli, J. A., ... \& Hotez, E. (2021). Impact of the COVID-19 Pandemic on Parent, Child, and Family Functioning. Family Process.

Franklin, B. (1993). Çocuk hakları [Children's rights]. Ayrıntı.

Freedson, J. (2021). Children's Right to be Heard: We're talking; are you listening? Joining Forces for All Children. Policy Briefs. https://resourcecentre.savethechildren.net/ library/childrens-right-be-heard-were-talking-are-you-listening. Accessed on 20.04.2021.

Fountain, S. (1993). It's only right- a pratical guide to learning about the convention on the rights of the child. UNICEF.

Gelber, D., Castillo, C., Alarcón, L., Treviño, E., \& Escribano, R. (2021). COVID-19 and the right to education in Chile: An opportunity to revisit our social contract. International review of education, 1-23. Advance online publication. https://doi.org/10.1007/s11159-021-09881-2 .Accessed on 19.04.2021.

Glesne, C. (2020). Nitel araştırmaya giriş. [Becoming Qualitative Researchers: An Introduction.]. An1.

González, J. L., Evangelista, A., \& Espinosa, C. (2021). Effects of the Pandemic on the Educational Trajectory of Children and Adolescents: Lessons from Chiapas, Mexico. Religación, 6, 53-68. 
Güçlü, S. (2016). Çocukluk ve çocukluğun sosyolojisi bağlamında çocuk hakları. [Children's rights in the context of childhood and its sociology] Sosyoloji Dergisi, [Journal of Sociology], (1), 1-22.

Haddad, C., Malhab, S. B., Sacre, H., Malaeb, D., Azzi, J., Khachman, D., ... \& Salameh, P. (2020). Factors related to Pregnancy Outcome Among Lebanese Women During COVID-19 Confinement.

Hamberg, T. (2012). Avrupa'da insan hakları [Human rights in Europe]. İletişim.

Hoyos D. R., \& Saavedra, J. (2021). It is time to return to learning. https://blogs.worldbank.org/education/it-time-return-learning. Accessed on 19.04.2021.

İnan, A. N. (1995). Çocuk hakları sözleşmesi [Children's rights convention]. A. ̈̈. Hukuk Fakültesi Dergisi, 1(4), 768- 769.

Jackson, C., Mangtani, P., Fine, P., \& Vynnycky, E. (2014). The effects of school holidays on transmission of varicella zoster virus, England and Wales, 1967-2008. PloS one, 9(6), e99762.

Josephson, A., Kilic, T., \& Michler, J. D. (2021). Socioeconomic impacts of COVID-19 in low-income countries. Nature Human Behaviour, 5(5), 557-565.

Karaman-Kepenekci, Y. (2010). An analysis on children's rights in stories recommended for children in Turkey, Journal of Peace Education, 7(1), 65-83, DOI: 10.1080/17400200903370985

Keskin, Y. \& Öğretici, B. (2013). Sosyal bilgiler dersinde "duyarlılık" değerinin etkinlikler yoluyla kazandırılması: Nitel bir araştırma. [Gaining the value of "sensitivity" through activities in social studies course: A qualitative research] Değerler Ĕgitimi Dergisi [ Journal of Values Education], 11(25), 143-181.

Larsen, L., Helland, M.S. \& Holt, T. (2021). The impact of school closure and social isolation on children in vulnerable families during COVID-19: a focus on children's reactions. European Child \& Adolescent Psychiatry. https://doi.org/10.1007/s00787-021-01758$\underline{x}$

Lightfoot, S. L. (1978). Worlds apart: Relationships between families and schools. Basic Books.

Merriam, S. B. (2013). A guide for qualitative research, design, and practice. Nobel.

Miles, M. B., \& Huberman, A. M. (1994). Qualitative data analysis: An expanded sourcebook. Sage.

Misirli, O., \& Ergulec, F. (2021). Emergency remote teaching during the COVID-19 pandemic: Parents experiences and perspectives. Education and Information Technologies. https://doi.org/10.1007/s10639-021-10520-4

Nelken, D. (1998). Afterword: choosing rights for children's. G. Douglas \& L. Sebba (Eds). Children's rights and traditional values. Nijhoff Publishers.

Osler, A., \& Starkey, H. (1998). Children's rights and citizenship: Some implications for the management of schools. International Journal of Children's Rights, 6(3), 313-333.

Palkovitz, R., \& Fagan, J. (2021). Faces of risk and resilience: fathers and their families. Adversity and Resilience Science. https://doi.org/10.1007/s42844-021-00034-w

Patrick, S. W., Henkhaus, L. E., Zickafoose, J. S., Lovell, K., Halvorson, A., Loch, S., Letterie, M., \& Davis, M. M. (2020). Well-being of parents and children during the COVID-19 pandemic: A national survey, Pediatrics,146(4), e2020016824 https://doi.org/10.1542/peds.2020-016824.

Patton, M. Q. (2014). Qualitative research and evaluation methods. Pegem: Ankara.

Pietrabissa, G., Volpi, C., Bottacchi, M., Bertuzzi, V., Usubini, A. G., Löffler-Stastka, H., Prevendar, T., Rapelli, G., Cattivelli, R., Castelnuovo, G., Molinari, E., \& Sartorio, A. (2021). The Impact of Social Isolation during the COVID-19 Pandemic on Physical 
and Mental Health: The Lived Experience of Adolescents with Obesity and Their Caregivers. Public Health, 18, 3026. https://doi.org/10.3390/ijerph18063026

Plan International, (2021). Living under lockdown girls and Covid-19. https://planinternational.org/publications/living-under-lockdown. Accessed on 19.04.2021.

Prime, H., Wade, M., \& Browne, D. T. (2020).Risk and resilience in family well-being during the COVID-19 pandemic. American Psychologist, 75(5), 631-643. https://doi.org/10.1037/amp0000660.

Rashid, H., Ridda, I., King, C., Begun, M., Tekin, H., Wood, J. G., \& Booy, R. (2015). Evidence compendium and advice on social distancing and other related measures for response to an influenza pandemic. Paediatric respiratory reviews, 16(2), 119-126.

Riddell, S., \& Tisdall, E. K. M (2021) Transforming children's rights? Dilemmas, challenges and implementation, Journal of Social Welfare and Family Law, 43(1), 1-7, DOI: 10.1080/09649069.2021.1876304

Rogers, G., Perez-Olivas, G., Kroese, S. B., Patel, V., Murphy, G., Rose, J., Cooper, V., Langdon, E.P., Hiles, S., Clifford, C., \& Willner, P. (2021). The experiences of mothers of children and young people with intellectual disabilities during the first COVID-19 lockdown period. Journal of Applied Research Intellectual Disabilities, OO(1), 1-10. https://doi.org/10.1111/jar.12884

Saavedra, J. (2020). Educational challenges and opportunities of the Coronavirus (COVID19) pandemic. https://blogs.worldbank.org/education/educational-challenges-andopportunities-covid-19-pandemic Accessed on 14.04.2021.

Saran, S. (2020). Technology: Digital Epiphany? COVID-19 and Our Tech Futures. In Insight Report Challenges and Opportunities in the Post-COVID-19 World (pp. 24-27). Geneva: World Economic Forum. www.weforum.org.

Sardohan-Yıldırım, A., \& Bozak, B. (2021). COVID-19 sürecinde çoklu yetersizliği olan çocukların ailelerine sunulan destekler: Bir durum çalışması. [Support for families of children with multiple disabilities in the COVID-19 process: a case research)] Yaşadıkça Ĕgitim, 35(1), 154-172. https://doi.org/10.33308/26674874.2021351247

Schwartzman, R. (2020). Performing pandemic pedagogy. Communication Education, 69(4), $502-517$.

Sezoran, R. (2005). Çocuk hukuku [Children's law]. Vedat.

Shen, K., Yang, Y., Wang, T., Zhao, D., Jiang, Y., Jin, R., ... \& Gao, L. (2020). Diagnosis, treatment, and prevention of 2019 novel coronavirus infection in children: experts' consensus statement. World journal of pediatrics, 16(3), 223-231.

Shosha, G. (2012). Employment of Colaizzi's strategy in descriptive phenomenology: a reflection of a researcher. European Scientific Journal, 8(27), 31-43.

Sığrı, Ü. (2021). Nitel araştırma yöntemleri. [Qualitative research methods]. Beta.

Smith, C., \& Ndeda, N. (2021). Lebanon education in crisis: Raising the alarm. Save the Children International.

Suleman, S., Ratnani, Y., Stockley, K., Jetty, R., Smart, K., Bennett, S., ... \& Loock, C. (2020). Supporting children and youth during the COVID-19 pandemic and beyond: A rights-centred approach. Paediatrics \& child health, 25(6), 333-336.

Tanrıbilir, F. B. (2011). Çocuk haklarının uluslararası korunması ve koruma mekanizmaları [International protection of children's rights and mechanisms of protection]. Ankara: Yetkin.

Tar, E., \& Atik, D. (2020). Pandemi döneminde çocuklarda obezite riski [Obesity risk in children during pandemic period]. Nursing Forum Journal in Diabetes, Obesity and Hypertension, 12(2), 37-41. 
Thomeer, M.B., Yahirun, J., \&, Colón-López, A. (2020), How families matter for health inequality during the COVID-19 pandemic. Journal of Family Theory Review, 12(4), 448-463. https://doi.org/10.1111/jftr.12398

Tuna, C. (2020). Çocuk hakları sözleşmesinde çocuğa tanınan haklar. [Rights granted to the child in the children's rights convention]. E. Hareket (Ed). Disiplinlerarası yaklaşımla çocuk hakları [Children's Rights with an Interdisciplinary Approach] (pp.75-97). Pegem.

Uçuş, Ş. (2013). Preparation and evaluation of the child rights education program. [Unpublished doctoral dissertation]. Hacettepe University, Institute of Educational Sciences.

UNICEF (2018). Çocuk haklarl sözleşmesi [Children's rights convention]. http://www.unicef.org/turkey/crc/_cr23b.html. Accessed on 19.04.2021.

UNICEF (2020). Is my child's development upset by the COVID-19 epidemic? https://www.unicef.org/turkey/hikayeler/\%C3\%A7ocu\%C4\%9Fumungeli\%C5\%9Fimi-covid-19-salg\%C4\%B1n\%C4\%B1-nedeniyle-geriliyor-mu. Accessed on 19.04.2021.

UNICEF (2020). Violence against children and adolescents in the time of COVID-19. https://www.unicef.org/lac/en/reports/violence-against-children-and-adolescents-inthe-time-of-covid-19. Accessed on 19.04.2021.

Unutkan, Ö.P. (2008). İnsan haklarl, çocuk haklarl ve ĕgitimi [Human rights, children's rights and education]. Pegem.

Van-Manen, M. (1990). Researching lived experience: Human science for an action sensitive pedagogy. State University of New York Press.

Wang, G., Zhang, Y., Zhao, J., Zhang, J., \& Jiang, F. (2020). Mitigate the effects of home confinement on children during the COVID-19 outbreak. The Lancet, 395(10228), 945-947.

Wanyana, D., Wong, R., \& Hakizimana, D. (2021). Rapid assessment on the utilization of maternal and child health services during COVID-19 in Rwanda. Public health action, 11(1), 12-21. https://doi.org/10.5588/pha.20.0057

Westrupp, E. M., Stokes, M. A., Fuller-Tyszkiewicz, M., Berkowitz, T. S., Capic, T., Khor, S., ... \& Hutchinson, D. (2021). Subjective wellbeing in parents during the COVID-19 pandemic in Australia. Journal of Psychosomatic Research, 145, 110482.

World Bank (2020). The COVID-19 Pandemic: Shocks to Education and Policy Responses, https://www.worldbank.org/en/topic/education/publication/the-covid19-pandemicshocks-to-education-and-policy-responses. Accessed on 19.04.2021.

Yıldırım, A., \& Şimşek, H. (2016). Sosyal bilimlerde nitel araştırma yöntemleri [Qualitative research methods in the social sciences]. Seçkin. 